\title{
Palatability and feeding behaviour in ruminants. A review
}

\author{
R Baumont \\ Station de recherches sur la nutrition des herbivores, Centre de recherche Inra \\ de Clermont-Ferrand-Theix, 63122 Saint-Genès-Champanelle, France
}

(Received 18 January 1996; accepted 15 May 1996)

\begin{abstract}
Summary - Palatability usually designates those characteristics of a feed that invoke a sensory response in the animal, and is considered to be the corollary of the animal's appetite for the feed. When only one feed is given to animals fed indoor, palatability can be evaluated by the eating rate at the beginning of the meal. When several feeds are studied, preference tests are most often used to assess palatability. Intake measurements are critical since postingestive effects are partly confounded with palatability, but experimental procedures allow these two variables to be separated. Behavioural measurements assess motivation for a feed rather than intake. Operant conditioning procedures show how animals maintain their choice for a preferred feed as it becomes increasingly difficult to obtain. Physical characteristics of the feed (particle size, resistance to fracture, dry matter content, height and density of sward, etc) contribute to the sensory response invoked by the animal. They influence ease of prehension and ease of mastication and animals generally prefer the physical form of the feeds they can eat faster. Taste and odour are recognized as of importance in feed palatability; however, effects of the primary tastes depend on the experimental procedures used. Nevertheless, there is some evidence that sheep will develop a liking for the taste of monosodium glutamate and for the odour of butyric acid and a dislike for acetic acid. Most of the palatability studies are short term with time scales of minutes or hours. In the long term (several days or weeks), feed preferences seem generally to be associated with digestive modifications. Animals use their senses to learn to associate the postingestive effects of the feed with its sensory characteristics. Ruminants generally develop preferences for feeds that will provide a high satiety level rapidly. Thus, palatability measured as the sensory response invoked by the feed integrates its nutritive value. However, for a given nutritive value, sensory properties of the feed per se can stimulate or depress hedonic feeding behaviour. The role of hedonic behaviour on intake may be of particular importance in choice situations and for low producing animals. In a first approach, hedonic value of the feed can be assessed by the difference between the observed intake and the predicted intake as affected by the nutritive value.
\end{abstract}

intake / palatability / feeding behaviour / forage / ruminant

Résumé - Appétibilité et comportement alimentaire chez les ruminants. L'appétibilité (ou la palatabilité) désigne les caractéristiques de l'aliment qui provoquent la réaction des sens de l'animal. 
Elle correspond au corollaire de l'appétit de l'animal pour l'aliment. Lorsqu'un seul aliment est disponible, l'appétibilité peut être évaluée par la vitesse d'ingestion au début du repas. Lorsque plusieurs aliments sont proposés, leur appétibilité est généralement évaluée par des tests de préférence. Mesurer la quantité ingérée pour évaluer l'appétibilité est critiquable car alors les effets postingestifs de l'aliment sont partiellement confondus avec celle-ci. Toutefois il existe des techniques expérimentales qui permettent de séparer les deux phénomènes. L'étude du comportement permet d'évaluer la motivation pour l'aliment plutôt que son résultat qui est la quantité ingérée. Les procédures de conditionnement opérant montrent comment l'animal maintient son choix pour un aliment préféré lorsqu'il devient de plus en plus difficile à obtenir. Les caractéristiques physiques de l'aliment (taille des particules, résistance à la cassure, teneur en matière sèche, hauteur et densité du couvert végétal...) participent à la réponse des sens. Elles influencent la facilité de préhension et de mastication et les animaux préfèrent généralement la forme physique des aliments qu'ils peuvent ingérer rapidement. Le goût et l'odeur sont considérés comme des déterminants importants de l'appétibilité. Mais les effets des goûts primaires dépendent de la technique expérimentale utilisée. Néanmoins il semble que le mouton aime le goût du monosodium glutamate et l'odeur de l'acide butyrique, mais n'aime pas l'acide acétique. La plupart des études sur l'appétibilité sont réalisées à court terme et ne portent que sur quelques minutes ou quelques heures. $\dot{A}$ long terme (plusieurs jours ou semaines) les préférences alimentaires semblent généralement être associées à des modifications digestives. Les animaux associent par apprentissage les effets postingestifs de l'aliment avec ses caractéristiques sensorielles. Les ruminants développent généralement des préférences pour les aliments qui leur permettent d'atteindre rapidement un état de satiété élevé. Ainsi l'appétibilité mesurée par la réponse des sens provoquée par l'aliment intègre sa valeur nutritive. Cependant, pour une valeur nutritive donnée, les propriétés sensorielles de l'aliment en elles-mêmes peuvent stimuler plus ou moins un comportement alimentaire de nature hédonique. Le rôle de ce comportement hédonique sur la quantité ingérée peut être important dans les situations de choix et pour les animaux à faibles niveaux de productions. En première approche, la valeur hédonique de l'aliment peut être assimilée à la différence entre la quantité ingérée observée et celle prévue à partir de sa valeur nutritive.

ingestion / appétibilité / palatabilité / comportement alimentaire / fourrage / ruminants

\section{INTRODUCTION}

To be consumed, a feed has first to be recognized as edible. The role of certain senses (ie, sight, smell, touch and taste) in the feeding behaviour of ruminants has been studied and reviewed by a number of authors (Arnold, 1970; Goatcher and Church, 1970a; Demarquilly, 1978; Church, 1979; Grovum, 1988). It is well established that the senses are used in selective grazing but they are probably less important when no choice is given to a stall-fed animal. Even in such a simple situation, however, it is impossible to describe voluntary feed intake for a wide range of feeds solely in terms of digestive and metabolic characteristics (Faverdin et al, 1995). Scientists interested in feed intake in ruminants have probably paid less atten- tion to the role of senses than to physical or energy control of intake. It is remarkable that none of the published feed intake prediction systems takes into account the sensory response to the feed.

The term palatability usually designates those characteristics of a feed that invoke a sensory response in the animal (Greenhalgh and Reid, 1971). This review discusses the concept of palatability for ruminants. After a brief presentation of the different definitions found in the literature, the methods used to evaluate palatability are reviewed and discussed. The main dietary factors involved in palatability and some aspects of the utilization of the senses by the animal are then analysed. Finally, we draw some conclusions concerning the role of palatability in the control of intake. 


\section{DEFINITIONS}

In accordance with the definition given by Greenhalgh and Reid (1971), Church (1979) defined palatability as the "dietary characteristics or conditions which stimulate a selective response by the animal", palatability being considered as an inherent characteristic of the feed (Hodgson, 1979). For Matthews (1983), the palatability of a feed is interchangeable with preference for the feed. It is determined by the taste, smell, appearance, temperature and texture of the feed. However, Forbes (1986, 1995a) claims that palatability cannot be considered solely as a quality of the feed since it depends on the experience and metabolic status of the animal in question; palatability of a feed is not absolute and depends on the state of hunger of the animal (Gallouin and Le Magnen, 1987). Palatability of the feed is the corollary of the appetite of the animal, which is the stimulation to eat aroused by the feed. Eating rate, especially at the beginning of the meal, is a good criterion of the animal's appetite, and palatability of the feed is defined as all the physical (plant bearing, spines, etc) and chemical (odour, taste, etc) characteristics of the feed that act on appetite (Jarrige, 1988). Mertens (1994) concurs with this last definition but does not mention physical characteristics of the plant; thus, it is not clear if the physical characteristics that determine ease of prehension and ease of mastication are components of palatability or not. At pasture, ease of harvesting has a major effect on diet selection as discussed by Dumont (1997). For animals fed indoors, it is well known that the same hay in long, chopped or ground form is not eaten at the same rate and in the same amount (Jarrige et al, 1995). As it is established that physical characteristics such as particle size and water content contribute to the sensory response invoked by the feed (see later) these are considered in this review as features of palatability.

\section{EVALUATING PALATABILITY}

Palatability is obviously not a quantitative measure unless feed intake is measured per unit time (Church, 1979). An ideal measure of palatability will not be influenced by the consequences of previous ingestion of feeds (Matthews, 1983) nor by the postingestive consequences of intake (Grovum and Chapman, 1988). Several methods are used to evaluate palatability. They differ according to what intake or behavioural parameters are recorded and whether only one or more than one feed is offered. However, none of these methods can avoid the effects of prior learning of feed characteristics.

\section{Intake measurements}

Differences in voluntary intake cannot be attributed only to palatability as they result from the sensory response and the digestive, metabolic and hormonal events following meals. Recording intake during the first minutes following exposure to the feed limits confusion of palatability with postingestive factors. A simple exponential model accurately fits intake rate during meals both in monogastric animals and ruminants (Davis et al, 1978; Faverdin, 1985; Baumont et al, 1989). This enables us to calculate initial eating rate at the beginning of the meal. In dairy cows fed on the same diet, the initial eating rate reflects the increase in eating motivation or "appetite" with the advance of lactation (Faverdin, 1985). When sheep have finished a first meal and the same hay is offered again, initial eating rates are similar for both meals (fig 1), although digestive and metabolic status are very different (Baumont et al, 1990). Initial eating rate, which can double from one forage to another, may thus be a good criterion for evaluating the sensory response invoked by a feed and thus its palatability. 


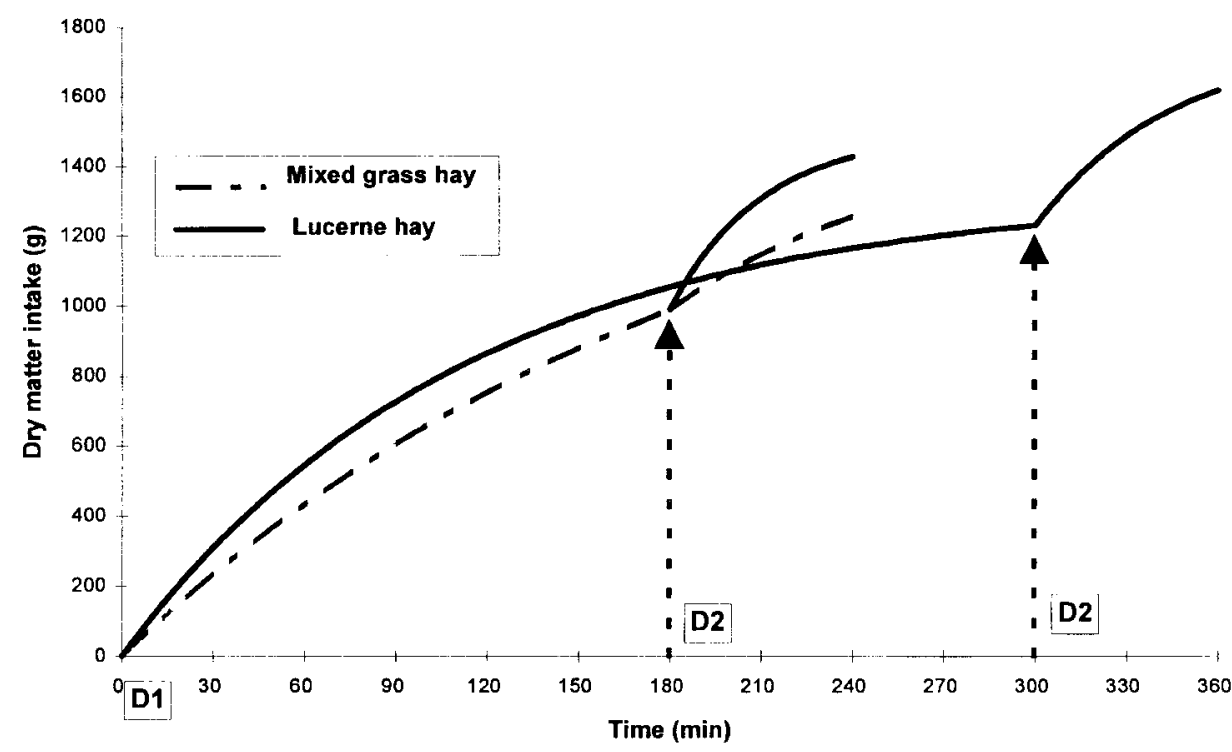

Fig 1. Kinetics of intake during the main meal following the morning feed (D1) and after a second feed (D2) 3 or $5 \mathrm{~h}$ later. Recordings are fitted on an exponential curve: $\mathrm{DMI}=A^{*}\left(1-e^{-b^{*}}\right)$, where $\mathrm{DMI}=\mathrm{dry}$ matter intake; $t=$ time; $A$ and $b=$ fitted parameters. Initial intake rate for $t=0$ is equal to $A^{\star} b$ (from Baumont et al, 1990).

Greenhalgh and Reid (1971) developed a method to isolate the effect of palatability from postingestive factors (fig 2). Considering two different feeds such as straw and dried grass, voluntary intake of each of the two feeds is measured with the same amount of the other feed introduced directly into the rumen through a fistula. In this way diet composition and digestibility are kept constant, and the difference in voluntary intake between the two feeds can be attributed to palatability. However, in a later experiment comparing chopped and pelleted hay, it was suggested that the rate of digestion of chopped hay is not the same if it is ingested or introduced through the fistula (Van Niekerk et al, 1973). This technique may therefore be unsuitable for measuring the relative palatability of feeds that differ greatly in physical structure unless ingestive mastication can be simulated. Another technique for avoiding postingestive effects is sham-feeding, in which the ingested feed is diverted from the digestive tract through an oesophageal fistula. This technique was used on sheep for palatability trials by Grovum and Chapman (1988).

Evaluating the effect of a given chemical compound on feed palatability through its taste or flavour means separating the effect of the chemical from the substrate in which it is incorporated. As no response to water could be detected in the goat, sheep and calf (Bell and Kitchell, 1966, quoted by Goatcher and Church, 1970a), water solutions were used to study the role of the primary tastes (Goatcher and Church, 1970b, c) and of several flavours (Arnold et al, 1980). In addition, the responses of normal animals to a given taste or odour can be compared with those of animals made agustatory and/or anosmic by surgical procedures (Arnold, 1966; Michalet-Doreau, 1975; Arnold et al, 1980). 


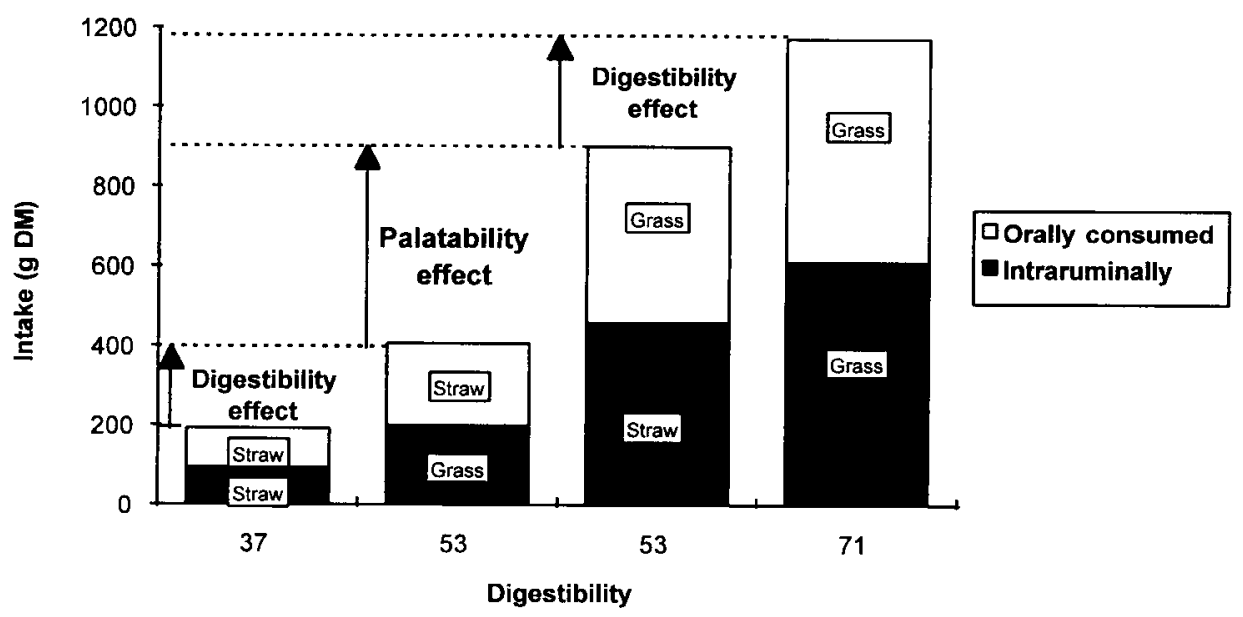

Fig 2. A method to separate the effect of digestibility from the effect of palatability on intake. Palatability is assessed by the difference in voluntary intakes between the two feeds studied measured with the other feed introduced in the rumen through a fistula in order to maintain diet composition and digestibility constant (after Greenhalgh and Reid, 1971).

Feeding behaviour is more sensitive to the different characteristics of feeds in a choice situation. Effects on intake of various odoriferous compounds vary in amplitude and sometimes even in sign according to whether the animals have a choice or not (Arnold, 1970). Thus, palatability trials should be performed in choice situations. However, the result of a choice test is influenced by the duration of the test and by the amounts of feed offered to the animals. If unlimited amounts are presented over short test durations, animals can show an exclusive preference for one single feed (Kertz et al, 1982). Conversely, if limited amounts of feeds are offered over long test durations all the feeds may be completely ingested (Hutson and Van Mourik, 1981). In either of these extreme situations intake measurements will not give a quantitative evaluation of the relative palatability of the tested feeds. Therefore, test procedures in choice situations have to be carefully defined. For example, to test palatability of concentrates on goats, Morand-Fehr et al (1987) defined the following procedure: i) feeds are tested in pairs; ii) the different combinations (six for four feeds to be tested) are set out in a latin square design; iii) each test lasts $30 \mathrm{~s}$ and is repeated four times with $200 \mathrm{~g}$ of each feed offered to the animal.

Colebrook et al (1985) developed a procedure to separate the role of physical characteristics that influence the potential intake rate of the feed from the other sensory factors. The procedure combines measurements of initial intake rate and of preference for the tested feed against a standard hay cut at different lengths (fig 3). Another interesting feature of this procedure is the use of a standard hay as a reference feed; the palatability of a given feed is relative to the palatability of the other feeds simultaneously presented.

\section{Behavioural measurements}

Behavioural measurements allow the evaluation of the motivation of the animal for 


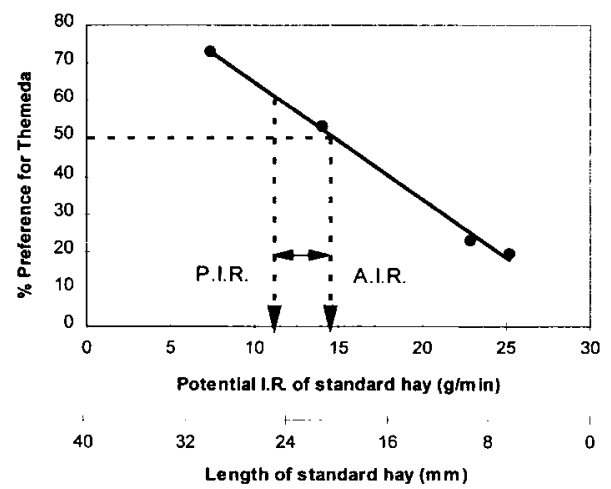

Fig 3. Quantitative measurement of relative palatability of feeds. Potential intake rates (PIR) (ie, intake rate for $1 \mathrm{~min}$ ) of the test forage and of different lengths of a standard hay are determined separately. The test forage is then offered in a preference test as a pair with several lengths of the standard hay. Preference for the test forage is regressed againt the intake rate of the standard hay. The intake rate of the standard hay with equal preference to the test forage is calculated to obtain the intake rate of the test forage adjusted (AIR) for sensory factors. The difference between PIR and AIR represents a quantitative measurement of the sensory factors influencing selection for the test forage relative to the standard hay (from Colebrook et al, 1985).

the feed rather than the result of this motivation, which is intake. Two different types of behaviour can be measured (Matthews, 1983): behaviour associated with eating freely-accessible feeds and behaviour that will gain access to elected feeds.

Under grazing conditions eating time is much easier to measure than intake. Grazing time has often been recorded at pasture and the differences in grazing times interpreted as differences in intake (Arnold, 1985). The time spent grazing on different sward types is considered to reflect the motivation for the different swards (Newman et al, 1992). Thus, time spent grazing is often used to evaluate preferences at pasture.
Monitoring grazing time allows an analysis of the temporal pattern of preference at pasture (Parsons et al, 1994). However, time spent grazing varies not only with the palatability of plants but also with the sward structure (height, density, etc).

Operant conditioning procedures are designed to study behaviour elicited to gain access to feeds (Baldwin, 1978; Matthews and Kilgour, 1980). In cattle a frequently used device consists of a nose-plate press. The animals have to carry out a defined behavioural sequence to be rewarded by feed. The relation between the occurrences of the responses (pushes) in the sequence and the feed deliveries is called the schedule of reinforcement (Matthews, 1983). Commonly, the schedules of reinforcement are based on numbers of responses (ratio schedules) or elapsed times (interval schedules). For example, in the progressive ratio procedure the number of responses required to be rewarded increases systematically. At a sufficiently high ratio the animals cease to respond. This procedure was used to assess the relative preference values of a range of different feeds when they were presented separately to individual sheep (Hutson and Van Mourik, 1981). Operant conditioning procedures are also used to evaluate feed preference under choice conditions. One of the advantages of this technique is that the measured behaviours at each alternative are identical and independent of the act of eating (Matthews, 1983). Furthermore, by varying the parameters of the reinforcement schedule it is possible to avoid exclusive behaviours. Under choice conditions operant procedures show how animals maintain their choice for the preferred feed as it becomes increasingly difficult to obtain. Dumont and Petit (1995) developed this learning procedure in which the animals had a choice between a poor quality forage offered ad libitum and a good quality one they could obtain in limited amounts each time they walked back and 
forth across the test area (fig 4). The procedure was used to compare sheep and cattle preferences when accessibility and availability of the preferred forage were equivalent for the two species. The procedure is promising as a means of testing relative palatability of different forages.

\section{THE MAIN FEED COMPONENTS OF PALATABILITY}

\section{Physical characteristics}

Since the work of Arnold (1966) it has been recognized that the sense of touch plays a role in the response of the animal to the feed. The sense of touch is used in selective grazing to avoid thorny and sticky plants. Physical characteristics of the forage such as dry matter content, particle size and resistance to fracture or height and density of the sward at pasture are known to affect ease of prehension and thus intake rate (Jarrige et al, 1995). Many measurements of voluntary intake and feeding behaviour were performed on chopped and ground-dehydrated forages by Jarrige et al (1973). When the mean particle size of the forage decreases voluntary intake increases, eating time decreases and thus intake rate increases markedly (see also Colebrook et al, 1985, fig 3). However, below a threshold of about $0.75 \mathrm{~mm}$ for legumes and about $0.5 \mathrm{~mm}$ for grasses the animal's response is reversed.

Physical characteristics of the feed act not only mechanically on ease of prehension, since it was shown in a choice situation that sheep generally prefer the feeds they can eat faster. With artificial sward boards, for a given density, the effect of sward height on relative preference was closely related to its effect on intake rate (Black and Kenney, 1984). Likewise, for a given height, the effect of density on relative preference is closely related to its effect on intake rate. With dried forages, relative preferences for mixtures with varying proportions of long and short particles were closely related to the differences in intake rates (Kenney and Black, 1984). Discrimination between the different mixtures decreases as intake rates of the feeds being compared increase. Accordingly, preference for short particles is more pronounced for a slowly ingested
Fig 4. A learning procedure technique to study relative palatability of forages. When the animal enters the test area, it has the choice between eating a bad quality feed ad libitum in manger $B$ or walking and being rewarded by a limited amount of a good quality feed in bucket a. When bucket a is empty the swivel system is turned and the animal has the choice between manger $\mathrm{A}$ and walking back to eat in bucket b (from Dumont and Petit, 1995).
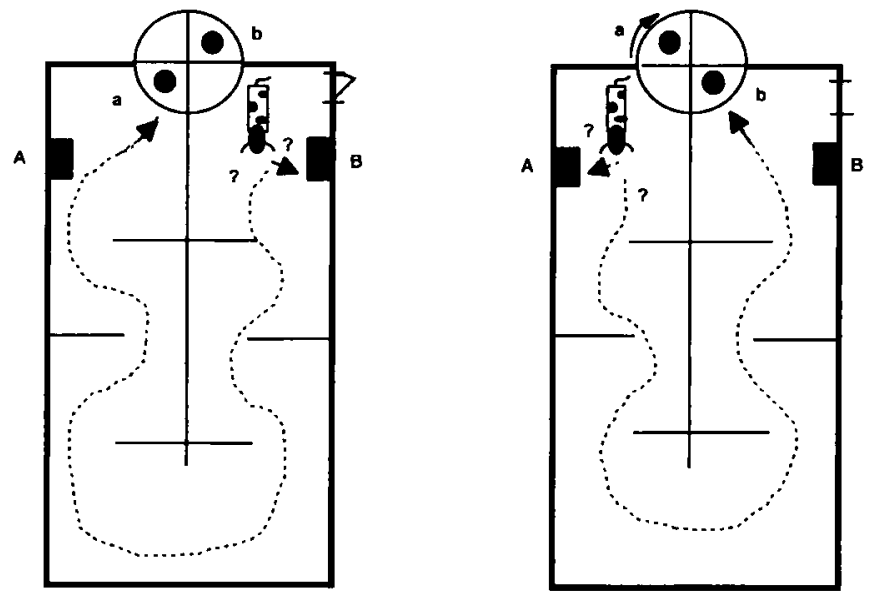
forage like straw than for rapidly ingested hay (fig 5).

Preference for forages which can be eaten fast may partly explain the close negative relationship between the energy necessary to grind the forage and voluntary intake (Chenost, 1966). Resistance to grinding is related to the cell-wall content and the percentage of stems in the forage (Chenost and Grenet, 1971). Thus, high resistance to grinding may explain the low palatability of straw and the high preference for straw in short versus long particles. Ryegrass selected for low leaf shear breaking load tends to be ingested with a higher intake rate (Inoué et al, 1994). Approximately $4 \%$ of the energy available to a sheep, from grass leaves, is estimated to be used during chewing (Wright, 1992).

Sheep showed some preference for undried forage over the same forage dried when intake was expressed as wet matter (Kenney et al, 1984). However, when expressed as dry matter, the proportions of total intake coming from the undried and the dried forage were similar. The influence of dry matter content on feed preferences thus seems to be of minor importance compared to that of particle size. In the same study, the forage chopped to a $10 \mathrm{~mm}$ length was preferred over the same forage cut to $40 \mathrm{~mm}$, irrespective of its dry matter content. These findings are consistent with observations made by studying the effect of mode of forage conservation. Making hay generally reduces voluntary dry matter intake, but this reduction seems not to be related to a drop in palatability since well conserved hays are ingested at the same rate as the corresponding green forages (Jarrige et al, 1995). In dairy cows drying the grass increases voluntary intake when the dry matter content of the fresh grass is lower than 15\% (Vérité and Journet, 1970). In sheep, the lower intake of long chopped grass silages than of short chopped silages is related to a markedly lower intake rate.

\section{Chemical characteristics}

Factors other than physical characteristics influence palatability. Without choice, legumes are always ingested at a higher rate than grasses, irrespective of particle size (Jarrige et al, 1973). In a choice situation, sheep develop a preference for lucerne over clover and for wheaten hay over wheaten straw when they are added to the

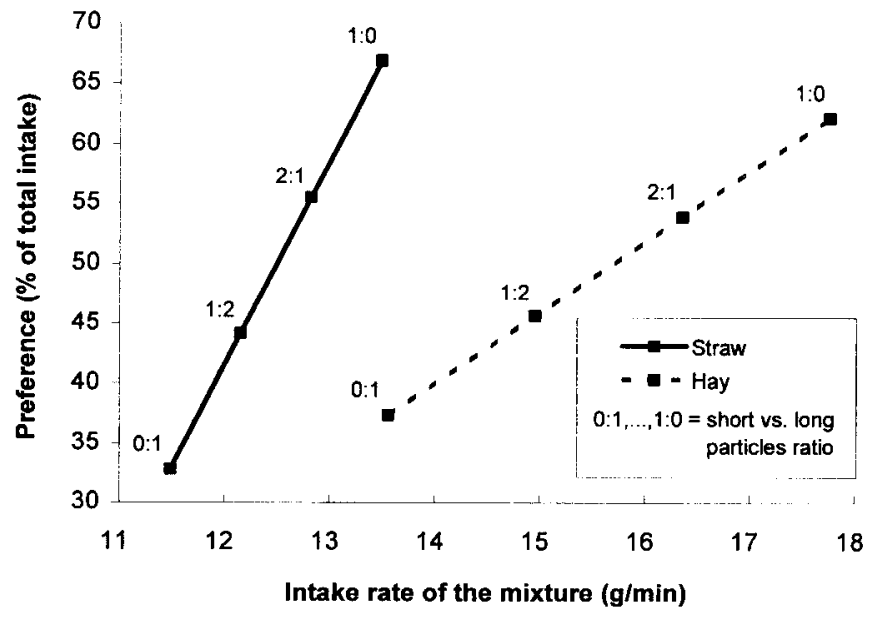

Fig 5. Relationships between the intake rate of a mixture of short and long particles and the preference for that mixture over a mixture of equal parts of long and short particles. Short and long material were mixed in proportions $0: 1,1: 2$, $2: 1$ and $1: 0$ on a weight basis for each forage (adapted from Kenney and Black, 1984). 
same basal diet in the ratio of 1 to 10 (Kenney and Black, 1984).

The effects of the primary tastes (sweet, salty, bitter, sour) were studied with water solutions (Goatcher and Church, 1970b, c) and with sham intakes on oesophageal-fistulated sheep (Grovum and Chapman, 1988). The results varied according to the method used (table I) particularly for sweet and salty tastes. Grovum and Chapman (1988) argued that the absence of postingestive effects (eg, modifications of $\mathrm{pH}$ and osmotic pressure) in their study explains the difference between their results and those of the trials performed with water solutions. However, Forbes (1995a) pointed out that oesophageal-fistulated sheep can lose saliva through the fistula and become sodium-deficient, thereby developing a preference for salty feeds. The specific taste of monosodium glutamate is called umami and is reported to be a combination of sweet and salty tastes (Goatcher and Church, 1970a). Its positive effect on palatability (table I) was also demonstrated by treating hay with an aqueous solution of monosodium glutamate (Gherardi and Black, 1991).

The effects of various odoriferous compounds were analysed by Arnold (1970) and Arnold et al (1980) by sprinkling the chem- icals onto cotton wool pads placed in the manger. The difficulty was in controlling the level of odour being tested. Odoriferous compounds were also studied with preference tests for different water solutions. The difficulty then was to separate the response through smell from the response through taste. For these reasons, anosmic and agustatory sheep were used in comparison with normal ones (Arnold et al, 1980). As stated earlier, effects of odoriferous compounds can vary in amplitude and sometimes in sign according to whether the animals are in choice situations or not. Amyl acetate has a positive effect on voluntary intake in a nochoice situation and a negative one in a free choice situation (Arnold, 1970). Coumarin depresses voluntary intake in a no-choice situation whereas sheep develop a liking for coumarin in a free choice situation. Several results indicate that sheep can develop a liking for butyric acid irrespective of whether they have a choice or not (Arnold et al, 1980; Gherardi and Black, 1991). However, with water solutions butyric acid or butyric sodium salt were shown to have negative effects on feed preference as also were acetic acid and propionate in acid or salt form (Goatcher and Church, 1970b, c). The negative effect of acetic acid was confirmed in a preference test for water solutions, but not when tested as an odour con-

Table I. Dose-related responses of sheep to the primary tastes according to whether they are studied with sham intakes on oesophageal-fistulated animals (Grovum and Chapman, 1988), or with preference test procedures for chemicals diluted in water (Goatcher and Church, 1970b, c).

\begin{tabular}{|c|c|c|c|}
\hline Taste & Chemical & Effect on sham intake & Preference for the chemical agai \\
\hline & $\ldots$ & & \\
\hline $\begin{array}{l}\text { Sweet } \\
\text { Salty }\end{array}$ & $\begin{array}{c}\text { Sucrose } \\
\mathrm{NaCl}\end{array}$ & $\stackrel{\text { linear } \downarrow}{\uparrow \text { regardless of the dose }}$ & $\begin{array}{c}\uparrow \text { at the highest dose } \\
\text { linear } \downarrow\end{array}$ \\
\hline Sour & $\mathrm{HCl}$ & $\downarrow$ at the highest dose & linear $\downarrow$ \\
\hline Bitter & Urea & $\downarrow$ regardless of the dose & variable \\
\hline Umami & MSG & $\uparrow$ at high doses & non-tested \\
\hline
\end{tabular}


taminant (Arnold et al, 1980). The palatability of hay was decreased by treating it with an aqueous solution of acetic acid (Gherardi and Black, 1991) and the shamintake of lucerne silage was linearly decreased with increasing the addition of acetic acid (Buchanan-Smith, 1990).

The low intake of silage is often attributed to a lack of palatability since digestibility is only slightly different from that of the corresponding green forage (Demarquilly, 1978). Effects of smell and taste on silage intake were studied with anosmic and agustatory sheep (Michalet-Doreau, 1975). The results must be interpreted with caution since anosmic sheep eat more than normal sheep (Arnold et al, 1980). Nevertheless, the increase in silage intake by anosmic sheep compared to normal animals was more pronounced with badly preserved silages $(+33 \%)$ than with well preserved ones $(+6.4 \%)$. However, silage intake by agustatory sheep was not modified. With dairy cows, flavouring agents will increase grass silage intake by about $8 \%$ over an 8 week period (Weller and Phipps, 1989). The study on sham-fed animals of the role of several constituents commonly found in silage juice gave unexpected results (Buchanan-Smith, 1990). Only acetic acid added alone had a clear negative effect on sham intakes whereas lactic and acetic acids together enhanced silage intake while acetic and butyric acids together and also ammonia had no effect on intake. A mixture of free amino acids decreased intake only at the highest concentration. A mixture of two amines and gamma-amino butyric acid increased intake at intermediate concentrations. However, amines alone are suspected to decrease palatability as in sheep initial eating rate at the beginning of the meal was depressed by addition of amines in the silage (Van Os et al, 1995). The effects of artificial flavours or of sweeteners seem to depend on the basal palatability of the treated forage. Sweeteners such as molasses caused manure-affected plants to be grazed (Marten and Donker, 1964). In contrast, the addition of molasses to normally palatable pelleted hay increases intake only slightly and for a short time (Kare, 1959, quoted by Demarquilly, 1978).

Most of the studies in which feeds are modified are short-term studies with a time scale of minutes or hours. Arnold et al (1980) added to pelleted hay small quantities of several compounds recognized to decrease intake by their odour or to decrease preference for a water solution by their taste (table II). Over a 3 day period, significant depressions in intake were obtained with coumarin, gramine, tannic acid, malonic acid and glycine. However, sheep that were both anosmic and agustatory were affected in the same way as normal sheep. In vitro digestibility of the pelleted hay was drastically depressed by tannic acid and gramine, and slightly by coumarin and glycine, but was unaffected by the other contaminants. In short-term preference studies, palatability of wheaten hay could be increased by adding a combination of butyric acid plus monosodium glutamate or decreased by magnesium oxide (Gherardi and Black, 1991). In a longterm study over 25 days (Gherardi et al, 1991), the voluntary intake of hay treated with butyric acid plus monosodium glutamate was $10 \%$ higher than that of untreated hay. This increase in intake was associated with an increase in the apparent fractional rate of digestion in the rumen. The high preference for the treated hay was maintained over 25 days. Voluntary intake of hay treated with magnesium oxide was not decreased over 25 days, even though ruminal digestion was depressed and thus compensated for by an increase in rumen fill. In preference tests, however, aversion to hay treated with magnesium oxide was maintained. Long-term effects on feed preferences or on voluntary intake seem to be generally 
associated with modification of digestive parameters.

\section{UTILIZATION OF THE SENSES IN FEEDING BEHAVIOUR}

As judged from the long-term effects of modifications of feed palatability, animals seem to be able to associate the sensory characteristics of a given feed with its nutritional consequences after feeding.

\section{Learning the postingestive effects of feeds}

The senses that are stimulated in the presence of feed enable the animal to anticipate the postingestive effects of feed. This effect has been extensively reviewed in rats by Le Magnen (1985). Provenza et al (1992) proposed a schematic representation of the processes involved in the learning of feed preferences. The affective system integrates the taste of a feed with postingestive feedback and the cognitive system integrates the odour and sight of the feed with its taste. Learned food aversions against toxic plants or feeds experimentally laced with several compounds that cause malaise have been clearly established in ruminants and in other mammals (Burrit and Provenza, 1989; du Toit et al, 1991; Ralphs and Cheney, 1993). Learned preferences based on positive nutritional postingestive feedback are undoubtedly also important for ruminants. Lambs, after 10 days adaptation, developed a strong preference for non-nutritive flavours paired with glucose over the same flavours paired with saccharin (Burrit and Provenza, 1992; table III). Thus, ruminants, like other mammals, develop preferences for feeds that provide more energy (Provenza, 1995). In sheep fed half orally and half intraruminally oral consumption of straw was doubled when digestibility was increased by dosing grass in the rumen instead of straw (fig 2). In contrast, oral consumption of grass decreased when straw was dosed in the rumen instead of grass. These results, together with those stated earlier (Arnold et al, 1980; Gherardi et al, 1991), must be interpreted as the consequences of learning the nutritive value of the diet. However in a free

Table II. Effect on intake (over a 3 day period) of several chemical compounds according to whether they are tested as odour contaminants or mixed in the diet; and corresponding effect on in vitro digestibility of the diet in the second case (from Arnold, 1970; Arnold et al, 1980).

\section{Chemicals}

$\frac{\text { Effect on intake (\% of variation from control) }}{\text { as odour contaminant mixed in the diet }}$

Coumarin

Gramine

Tannic acid

Malonic acid

Glycine

Glutamic acid

Malic acid

Quinic acid

-9.3
non-tested
$-18^{\star}$
$-29^{*+}$
-18
0
$-14^{\star+}$
$-8.6^{\star+}$

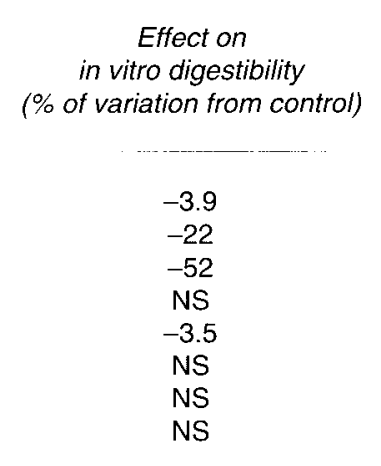

* In choice situation; + tested in water solution; NS: not significant. 
choice situation, diet selection will not always maximize energy density of the diet. Sheep eat some straw to prevent rumen disorders even though a more concentrated feed is also on offer (Cooper et al, 1995). This is consistent with the observation that sheep maintain $10 \%$ of chopped forage in their diet when offered a free choice of the same forage chopped or pelleted (Greenhalgh and Reid, 1974). Moreover, dietary experience in early life was shown to have a significant effect on consumption of low-quality roughage and diet selection in free choice situations (Distel et al, 1994). Processes of learning from the mother, from conspecifics and through trial and error have been reviewed (Provenza et al, 1992; Provenza, 1995).

Animals use the senses of smell and sight to detect subtle differences in feeds and select or avoid specific feed items. The anticipation role of the senses may explain why in cows a barley supply significantly decreased subsequent hay intake when fed orally, but not when added to the rumen (Baumont et al, 1994, table IV). The anticipatory role of the senses may also explain why anosmic sheep eat more than normal sheep (Arnold et al, 1980). These observations are consistent with the finding that, for rats, olfactory cues are not only involved in palatability but also in the control of energy intake (Larue and Le Magnen, 1972). Anticipation by the senses of postingestive effects explains to a certain extent the diurnal pattern of preference (Parsons et al, 1994).

\section{Hedonic behaviour}

Intake is primarily a behaviour influenced by hunger, which is distressing, and by satiety, which is generally pleasurable (Read, 1992). Recently, Forbes (1995b) postulated that "ruminants eat that amount of food which leaves them with the most comfortable feelings". Qualitative, quantitative and affective components can be discerned in the complex sensations perceived in humans during intake (Fantino, 1992). The first two components afford recognition of the nature and amounts of feed ingested. The third component, the so-called hedonic perception, is related to pleasant or unpleasant feelings evoked by the feed. Hence, mechanisms of brain reward can to some extent induce hedonic feeding behaviour in competition with physiological factors controlling intake. The palatability of the feed will stimulate hedonic behaviour to a greater or lesser extent. Total intake of sheep was only $406 \mathrm{~g} /$ day when they ate straw and received grass in the rumen but rose to $901 \mathrm{~g} /$ day in the reverse situation, although digestibility of the total diet was similar (Greenhalgh and Reid, 1971; fig 2). Unpleasant feelings when eating straw may explain its very low hedonic value. With good

Table III. Development of a preference for the flavour paired with glucose over the flavour paired with saccharin after 10 days conditioning in lambs (from Burrit and Provenza, 1992).

Glucose

( $m L$ of solution consumed)
Initial hedonic preference

Preference for the flavour paired with
$455 \pm 47$

$840 \pm 111$
$439 \pm 46$

$32 \pm 17$ 
quality forages fed to wethers, observed voluntary intakes greatly in excess of requirement can be explained by hedonic behaviour (Baumont et al, 1989). The sensory response induced by a second distribution of fresh hay will override the satiety signals induced by the meal following the first distribution (Gatel, 1984). However, the size of the second meal depends on the relative palatability of the two hays distributed (Baumont et al, 1990). Sheep satiated with low-quality meadow hay will eat $400 \mathrm{~g}$ of lucerne hay (fig 1); however, they are reluctant to eat meadow hay when satiated with lucerne.

Hedonic behaviour also competes with the effort that has to be expended to earn the reward. In a test situation, when animals have to walk to obtain a good forage, the preference for the good forage depends on the amount offered the animals in reward (Dumont and Petit, 1995).

\section{CONCLUSION: PALATABILITY AND CONTROL OF INTAKE}

The sensory response invoked by a feed is expressed by the intake rate when no choice is offered to the animal and by the feed pref- erences in choice situation. It integrates the postingestive effects that the animal has learned to associate with its sensory properties and it interacts with the nutrient requirements of the animal. Meal size and diet composition are mainly controlled by anticipation of postingestive effects to avoid nutritional excesses or deficiencies. Ruminants generally develop preferences for feeds that will provide a high satiety level rapidly. Feeds that can be ingested fast and that are rapidly and highly digestible are very palatable provided they do not contain toxic compounds. Nevertheless, for a given nutritive value, sensory properties of the feed per se can stimulate or depress hedonic behaviour and thus intake. Indeed, residual variation in predictive models of voluntary intake based on nutritional characteristics (ie, energy and nitrogen values, fill effect) remains generally high. Thus, palatability measured as the sensory response invoked by a feed combines its nutritive and hedonic values (fig 6). Hedonic behaviour is probably more important in low-producing animals than in high-producing ones. Moreover, the effect of hedonic behaviour on intake is probably more important when choice is offered to the animals. In a first approach, the hedonic value of the feed can be assessed by the difference between the

Table IV. Effect of a barley supply $(2.7 \mathrm{~kg}$ of dry matter) on subsequent hay intake according to whether it is ingested or introduced in the rumen after mixing with artificial saliva (Baumont et al, 1994).

Whole day
First hour
Hay intake (kg DM)
ab Means on the same line without a common superscript differ $(P<0.05)$


observed and the predicted intake as affected by the nutritional characteristics. Several questions remain unanswered. Is it possible to increase intake in the long term by improving hedonic perception of the feed without also increasing the nutritive value? What exactly are the physical characteristics and chemical compounds that are used by ruminants to associate the sensory properties of feed with its nutritive value? Modern analytical methods to characterize texture and aromatic compounds in feeds may help in gaining a better understanding of the components determining palatability.

\section{FEED}

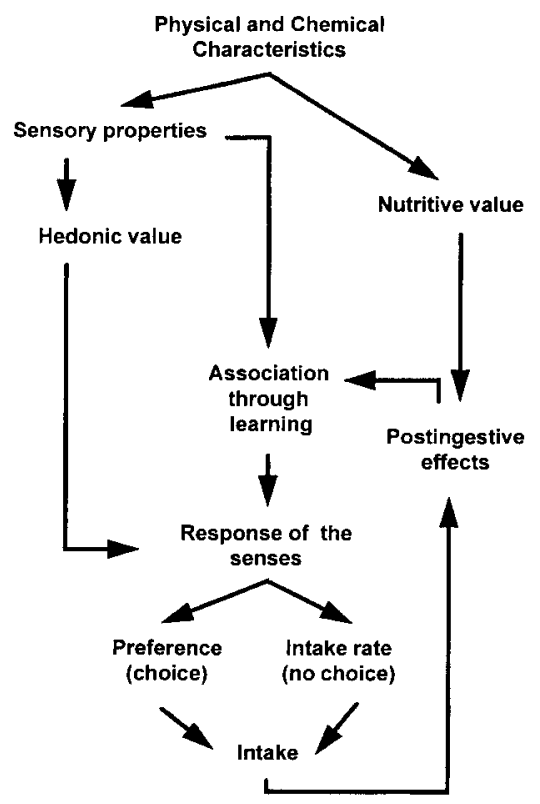

ANIMAL

Fig 6. Schematic diagram of the response of the senses to feed characteristics. The sensory properties of the feed influence hedonic behaviour and are associated with the nutritive value after learning. Palatability measured as the response of the senses integrates both aspects.

\section{REFERENCES}

Arnold GW (1966) The special senses in grazing animals. 2. Smell, taste and touch and dietary habits in sheep. Aust J Agric Res 17, 531-542

Arnold GW (1970) Regulation of food intake in grazing ruminants. In: Physiology of Digestion and Metabolism in Ruminants (AT Phillipson, ed), Oriel Press, 264-276

Arnold GW (1985) Ingestive behaviour. In: World Animal Science. 5. Ethology of Farm Animals (A Neimann-Sorensen, DE Tribe, eds), Elsevier Science, 183-198

Arnold GW, De Boer G, Boundy (1980) The influences of odour and taste on food preferences and food intake of sheep. Aust J Agric Res 31, 571-585

Baldwin BA (1978) Operant studies and preference test on the role of olfaction and taste in digestive behaviour of pigs and ruminants. In: First International Symposium on Palatability and Flavor Use in Animal Feeds, Zurich, Switzerland, 10-11 October 1978 (Institute of Animal Production, Swiss Federal Institute of Technology), 43-49

Baumont $R$, Brun JP, Dulphy JP (1989) Influence of the nature of hay on its ingestibility and the kinetics of intake during large meals in sheep and cow. In: XVIth International Grassland Congress, Nice, France (2) (R Jarrige, ed), French Grassland Society, 787-788

Baumont R, Seguier N, Dulphy JP (1990) Rumen fill, forage palatability and alimentary behaviour in sheep. J Agric Sci 115, 277-284

Baumont $R$, Daveau O, Perpère C (1994) A trial to quantify the roles of ruminal and oropharyngeal signals in the control of food intake by cows. In: Proceedings of the Society of Nutrition Physiology. $8^{e}$ International Symposium on Ruminant Physiology, Willingen, Germany, 25-30 September 1994 (D Giesecke, ed), DLG-Verlag, 122

Black JL, Kenney PA (1984) Factors affecting diet selection by sheep. 2. Height and density of pasture. Aust $J$ Agric Res 35, 565-578

Buchanan-Smith JG (1990) An investigation into palatability as a factor responsible for reduced intake of silage by sheep. Anim Prod 50, 253-260

Burrit EA, Provenza FD (1989) Food aversion learning ability of lambs to distinguish safe from harmful foods. $J$ Anim Sci 67, 1732-1739

Burrit EA, Provenza FD (1992) Lambs form preferences for non-nutritive flavors paired with glucose. J Anim Sci 70, 1133-1136

Chenost $M$ (1966) L'indice de fibrosité des foins : mesure et relations avec la valeur alimentaire. Ann Zootech 15, 253-257

Chenost M, Grenet E (1971) L'indice de fibrosité des fourrages : sa signification et son utilisation pour la 
prévision de la valeur alimentaire des fourrages. Ann Zootech 20, 427-435

Church DC (1979) Taste, appetite and regulation of energy balance and control of food intake. I. Appetite, taste and palatability. In: Digestive Physiology and Nutrition of Ruminants (DC Church, ed), Oxford Press, 281-290

Colebrook WF, Black JL, Kenney PA (1985) Effect of sensory factors on diet selection by sheep. Proc Nutr Soc (Austr) 10, 99-102

Cooper SDB, Kyriasakis I, Nolan JV (1995) Diet selection in sheep: the role of the rumen environment in the selection of a diet from two feeds that differ in their energy density. Br J Nutr 74, 39-54

Davis JD, Collins BJ, Levine MW (1978) The interaction between gustatory stimulation and gut feedback in the control of the ingestion of liquid diets. In: Hunger Models (DA Booth, ed), Academic Press, 109-143

Demarquilly C (1978) Intake, palatability and flavor in ruminant feeds. In: First International Symposium on Palatability and Flavor Use in Animal Feeds, Zurich, Switzerland, 10-11 October 1978 (Institute of Animal Production, Swiss Federal Institute of Technology), 91-98

Distel RA, Villalba JJ, Laborde HE (1994) Effects of early experience on voluntary intake of low-quality roughage by sheep. J Anim Sci 72, 1191-1195

du Toit JT, Provenza FD, Nastis AS (1991) Conditioned food aversions: How sick must a ruminant get before it detects toxicity in foods? Appl Anim Behav Sci30, 35-46

Dumont B (1997) Diet preference of herbivores on pasture. Ann Zootech (in press)

Dumont B, Petit M (1995) An indoor method for studying the preferences of sheep and cattle at pasture. Appl Anim Behav Sci 46, 67-80

Fantino M (1992) État nutritionnel et perception affective de l'aliment. In : Plaisir et préférences alimentaires (I Giachetti, ed), Polytechnica, 31-45

Faverdin P (1985) Régulation de l'ingestion des vaches laitières en début de lactation. Thèse de doctorat Ina-PG, France, $131 \mathrm{p}$

Faverdin P, Baumont R, Ingvartsen KL (1995) Control and prediction of feed intake in ruminants. In: Recent Developments in the Nutrition of Herbivores. Proceedings of the $\mathrm{Vth}$ International Symposium on the Nutrition of Herbivores. Clermont-Ferrand, France, 1995 (M Journet, E Grenet, MH Farce, M Thériez, C Demarquilly, eds), INRA Editions, 95-120

Forbes JM (1986) Dietary factors affecting intake. In: The Voluntary Intake of Farm Animals. Butterworths, London, UK, 86-113

Forbes JM (1995b) Voluntary Food Intake and Diet Selection in Farm Animals. CAB International, $532 \mathrm{p}$
Forbes JM (1995a) Physical limitation of feed intake in ruminants and its interactions with other factors affecting intake. In: Ruminant Physiology: Digestion. Metabolism, Growth and Reproduction. Proceedings of the Eighth International Symposium on Ruminant Physiology (WV Engelhardt, S Leonhard-Marek, $G$ Breves, D Giesecke, eds), Ferdinand Enke Verlag, 217-232

Gallouin F, Le Magnen J (1987) Évolution historique des concepts de faim, satiété et appétit. Reprod Nutr Dev 27, 109-128

Gatel F (1984) Signification de la satiété à court terme chez le mouton : influence de la qualité du fourrage et des stimuli associés à la prise de nourriture. Ann Zootech 33, 111-118

Gherardi SG, Black JL (1991) Effect of palatability on voluntary feed intake by sheep. 1 . Identification of chemicals that alter the palatability of a forage. Aust J Agric Res 42, 571-584

Gherardi SG, Black JL, Colebrook WF (1991) Effect of palatability on voluntary feed intake by sheep. 2 . The effect of altering the palatability of a wheaten hay on long-term intake and preference. Aust $J$ Agric Res 42, 585-598

Goatcher WD, Church DC (1970a) Review of some nutritional aspects of the sense of taste. J Anim Sci 31 . 973-981

Goatcher WD, Church DC (1970b) Taste responses in ruminants. 1. Reactions of sheep to sugars, saccharin, ethanol and salts. J Anim Sci30, 777-783

Goatcher WD, Church DC (1970c) Taste responses in ruminants. 2. Reactions of sheep to acids, quinine, urea and sodium hydroxide. J Anim Sci 30, 784-790

Greenhalgh JFD, Reid GW (1971) Relative palatability to sheep of straw, hay and dried grass. Br J Nutr 26 107-116

Greenhalgh JFD, Reid GW (1974) Long- and short-term effects on intake of pelleting a roughage for sheep. Anim Prod 19, 77-86

Grovum WL (1988) Appetite, palatability and control of feed intake. In: The Ruminant Animal, Digestive Physiology and Nutrition (DC Church, ed), Prentice Hall, 202-216

Grovum WL, Chapman (1988) Factors affecting the voluntary intake of food by sheep. 4 . The effect of additives representing the primary tastes on sham intakes by oesophageal-fistulated sheep. Br J Nutr 59, 63-72

Hodgson $J$ (1979) Nomenclature and definitions in grazing studies. Grass Forage Sci 34, 11-18

Hutson GD, Van Mourik SC (1981) Food preferences of sheep. Aust J Exp Agric Anim Husb 21, 575-582

Inoué T, Brookes IM, John A, Kolver ES, Barry TN (1994) Effects of leaf shear breaking load on the feeding value of perennial ryegrass (Lolium perenne) for sheep. 2. Effects on feed intake, particle breakdown, rumen digesta outflow and animal performance. $J$ Agric Sci 123, 137-147 
Jarrige R, Demarquilly C, Journet M, Beranger C (1973) The nutritive value of processed dehydrated forages with special reference to the influence of physical form and size particle. In: Proceedings of the First International Green Crop Drying Congress. E \& E Plumridge, 99-118

Jarrige R (1988) Alimentation des bovins, ovins et caprins. INRA Publications, $471 \mathrm{p}$

Jarrige R, Dulphy JP, Faverdin P, Baumont R, Demarquilly $C$ (1995) Activités d'ingestion et de rumination. In: Nutrition des Ruminants Domestiques ( $R$ Jarrige, $Y$ Ruckebusch, $C$ Demarquilly, MH Farce, $M$ Journet, eds), INRA, 123-181

Kenney PA, Black JL (1984) Factors affecting diet selection by sheep. I. Potential intake rate and acceptability of feed. Aust J Agric Res 35, 551-563

Kenney PA, Black JL, Colebrook WF (1984) Factors affecting diet selection by sheep. 3 . Dry matter content and particle length of forage. Aust J Agric Res $35,831-838$

Kertz AF, Koepke MK, Davidson LE, Betz NL, Norris JR, Skoch LV, Cords BR, Hopkins DT (1982) Factors influencing intake of high urea-containing rations by lactating dairy cows. J Dairy Sci 65, 587-604

Larue C, Le Magnen J (1972) The olfactory control of meal pattern in rats. Physiol Behav 9, 817-821

Le Magnen J (1985) Hunger. Problems in the Behavioural Sciences. Cambridge University Press, $151 \mathrm{p}$

Marten GC, Donker JD (1964) Selective grazing induced by animal excreta. I. Evidence of occurrence and superficial remedy. J Dairy Sci $47,773-776$

Matthews LR (1983) General introduction. In: Measurement and scaling of food preferences in dairy cows: concurrent schedule and free-access techniques. PhD Thesis, University of Waikato, New Zealand, $236 \mathrm{p}$

Matthews LR, Kilgour R (1980) Learning and associated factors in ruminant feeding behaviour. In: Digestive Physiology and Metabolism in Ruminants ( $Y$ Ruckebusch, P Thivend, eds), MTP, 123-144

Mertens DR (1994) Regulation of forage intake. In: Forage Quality, Evaluation and Utilization (GC Fahey, ed), $450-493$

Michalet-Doreau B (1975) Recherches sur les causes des variations des quantités d'ensilage d'herbe ingérées par les ruminants. Thèse Docteur-Ingénieur Université de Nancy, Nancy, France, $99 p$

Morand-Fehr P, Hervieu J, Legendre D, Gutter A, Del Tedesco $L$ (1987) Rapid tests to assess concentrate feed acceptability by goats. Ann Zootech 36, 324

Newman JA, Parsons AJ, Harvey A (1992) Not all sheep prefer clover: diet selection revisited. J Agric Sci 119, 275-283

Parsons AJ, Newman JA, Penning PD, Harvey A, Orr RJ (1994) Diet preference of sheep: effect of recent diet, physiological state and species abundance. $J$ Anim Ecol 63, 465-478

Provenza FD, Pfister JA, Cheney CD (1992) Mechanisms of learning in diet selection with reference to phytotoxicosis in herbivores. J Range Manage 45, 36-45

Provenza FD (1995) Role of learning in food preferences of ruminants: Greenhalgh and Reid revisited. In: Ruminant Physiology: Digestion, Metabolism, Growth and Reproduction. Proceedings of the Eighth International Symposium on Ruminant Physiology (WV Engelhardt, S Leonhard-Marek, G Breves, D Giesecke, eds), Ferdinand Enke Verlag, 233-247

Ralphs MH, Cheney CD (1993) Influence of cattle age lithium chloride dose level, and food type in the retention of food aversions. J Anim Sci 71, 373-379

Read NW (1992) Role of gastrointestinal factors in hunger and satiety in man. Proc Nutr Soc 51, 7-11

Van Niekerk AI, Greenhalgh JFD, Reid GW (1973) Importance of palatability in determining the feed intake of sheep offered chopped and pelleted hay. $\mathrm{Br}$ J Nutr 30, 95-105

Van Os M, Dulphy JP, Baumont R (1995) The effect of protein degradation products in grass silages on teed intake and intake behaviour in sheep. BrJ Nutr $73,51-64$

Vérité R, Journet M (1970) Influence de la teneur en eau et de la déshydratation de l'herbe sur sa valeur alimentaire pour les vaches laitières. Ann Zootech 19 , 255-268

Weller RF, Phipps RH (1989) Preliminary studies on the effect of flavouring agents on the dry-matter intake of silage by lactating dairy cows. J Agric Sci 112, 67-71

Wright W (1992) The Fracture Properties of Grasses and their Relevance to Feeding in Herbivores. University of Reading, $174 p$ 